УДК 654.1: 656.25

DOI: $10.15587 / 2313-8416.2015 .35902$

\title{
ТЕОРЕТИЧНЕ ОБГРУНТУВАННЯ КІЛЬКОСТІ КАНАЛІВ ПЕРЕДАЧІ ПОВІДОМЛЕНЬ В СИСТЕМІ АВТОМАТИЧНОГО ОПОВІЩЕННЯ
}

\author{
(C) С. О. Змій
}

Для підвищення безпеки робітників та пасажирів на залізничних станціях необхідно виконати їх оповіщення про небезпеку за встановлений час. Зменшення часу до початку оповіщення до встановленого значення можливе за рахунок збільшення, як кількості каналів передачі, так і визначення пріоритетів в обслуговуванні Ключові слова: пріоритет в обслуговуванні, кількість каналів, оповіщення, система автоматичного оповіщення, працюючі на коліях, пасажири

To improve the safety of workers and passengers at the railways stations need to perform their warning about danger in the stated time. Decreasing the time before the warning to the selected measure is possible by increasing the number of channels and prioritizing maintenance.

Keywords: service priority, number of channels, warning, automatic warning system, working on the railroad, passengers

\section{1. Ветуп}

Убезпечення виконання робіт працюючих на коліях залізничних станцій та безпека пасажирів на платформах залежить від своєчасності їх оповіщення про переміщення рухомого складу. Якщо ж оповіщення виконано значно заздалегідь, то працюючі на коліях або пасажири на платформах не будуть у повній мірі сприймати цю інформація та знижується довіра до системи оповіщення. Такі випадки трапляються при необхідності одночасного оповіщення декількох бригад працюючих на коліях та пасажирів.

\section{2. Постановка проблеми}

Проведені дослідження виконання операції оповіщення черговим по станції працівників та пасажирів на залізничних станціях показав недостатній рівень ймовірності своєчасності виконання зазначених дій [1]. Вирішенням проблеми $\epsilon$ використання систем автоматичного оповіщення, що виконують оповіщення всіх причетних до убезпеченого виконання робіт на коліях станції та попередження пасажирів на платформах: працівників на коліях, локомотивних бригад, чергового по станції та пасажирів. Але в існуючих вимогах до систем автоматичного оповіщення $[2,3]$ відсутні вимоги як до кількості каналів передачі, так і до послідовності оповіщення всіх зазначених працівників та пасажирів.

\section{3. Літературний огляд}

На даний час існує різноманіття систем автоматичного оповіщення, що використовують декілька каналів передачі інформації про переміщення рухомого складу. У діючому стандарті, що розповсюджується на системи автоматичного оповіщення [3] регламентовано лише мінімальний час, за який необхідно оповістити працюючих на коліях залізничних станцій та безпека пасажирів на платформах. У роботі [4] надано опис побудови та функціонування централізованої системи інформування та оповіщення, але відсутня інформація щодо обгрунтування кількості каналів передачі інформації.
4. Визначення кількості каналів передачі мовних повідомлень в системі автоматичного оповіщення

Час простою в очікуванні оповіщення $t_{o}$ викликаний тим, що за наявності декількох бригад або паралельних пересувань рухомого складу може виникнути ситуація, при якій необхідно одночасно використовувати канал для передачі інформації (рис. 1).

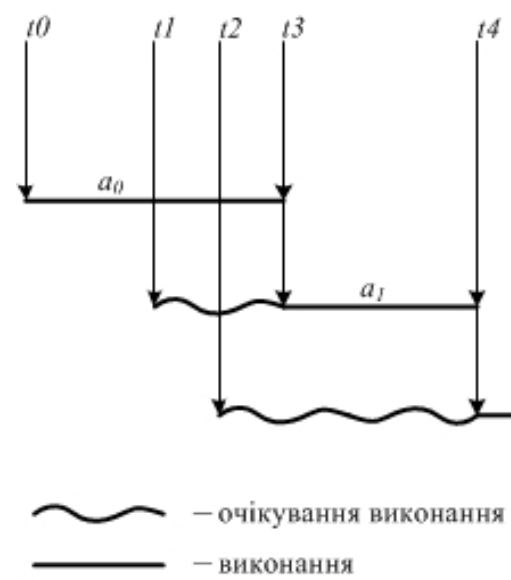

Рис. 1. Час простою в очікуванні оповіщення: ai - функція тривалості безперервного виконання оповіщення з k пріоритетом

Для вирішення цієї проблеми вводиться відносний пріоритет $k$ в обслуговуванні повідомлення. Час простою в очікуванні $t_{o}, з$ урахуванням [6], визначається по формулі:

$$
t_{o k}=t+\sum_{n=1}^{K} a_{k}+\frac{\lambda_{k-1} T_{k-1}}{\sum_{n=1}^{K} \lambda_{k-1} T_{k-1}} \cdot a_{k-1},
$$

де $t_{o k}-$ простій в очікуванні повідомленні з $k$-м пріоритетом, $\alpha_{k}-$ функція тривалості безперервного виконання, $\lambda_{k}$ - потік повідомлень; $T_{k}$ - час використання каналу повідомленням; $t$ - поточний час; $k$ - пріоритет повідомлення. 
Пріоритет $k$ в обслуговуванні повідомлення визначається рівнем небезпеки для людини (працівників на коліях залізничної станції, пасажирів), що знаходиться у небезпечній зоні.

Потік повідомлень $\lambda$ визначається потоком поїз-

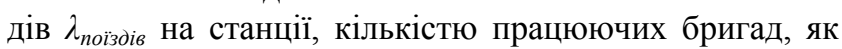

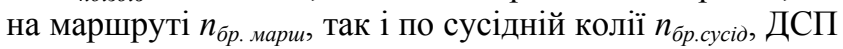
та інших працівників $n_{i p}$ :

$$
\lambda=\lambda_{\text {nої } \partial i 6}\left(n_{\text {бр.мари }}+n_{\text {бp. сусі⿱ }}+n_{i p}\right) .
$$

Так, при використанні одного каналу для передачі інформації значно зростає час, за який необхідно починати оповіщення (рис. 2).

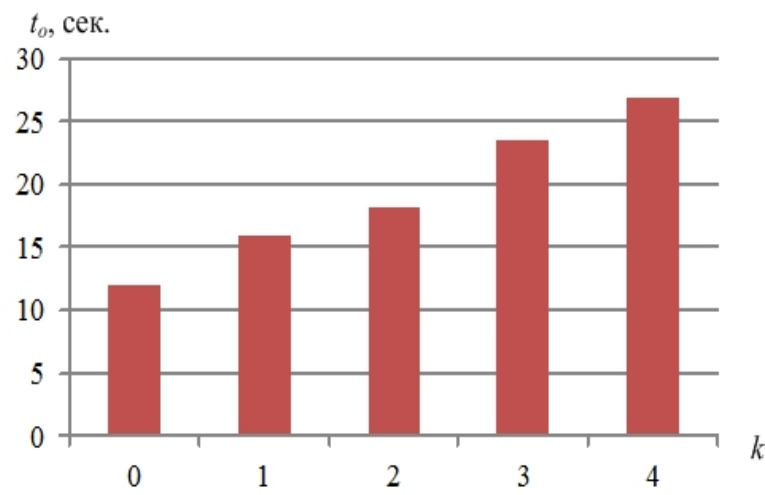

Рис. 2. Залежність простою в очікуванні оповіщення $t_{o}$ від пріоритету $k$

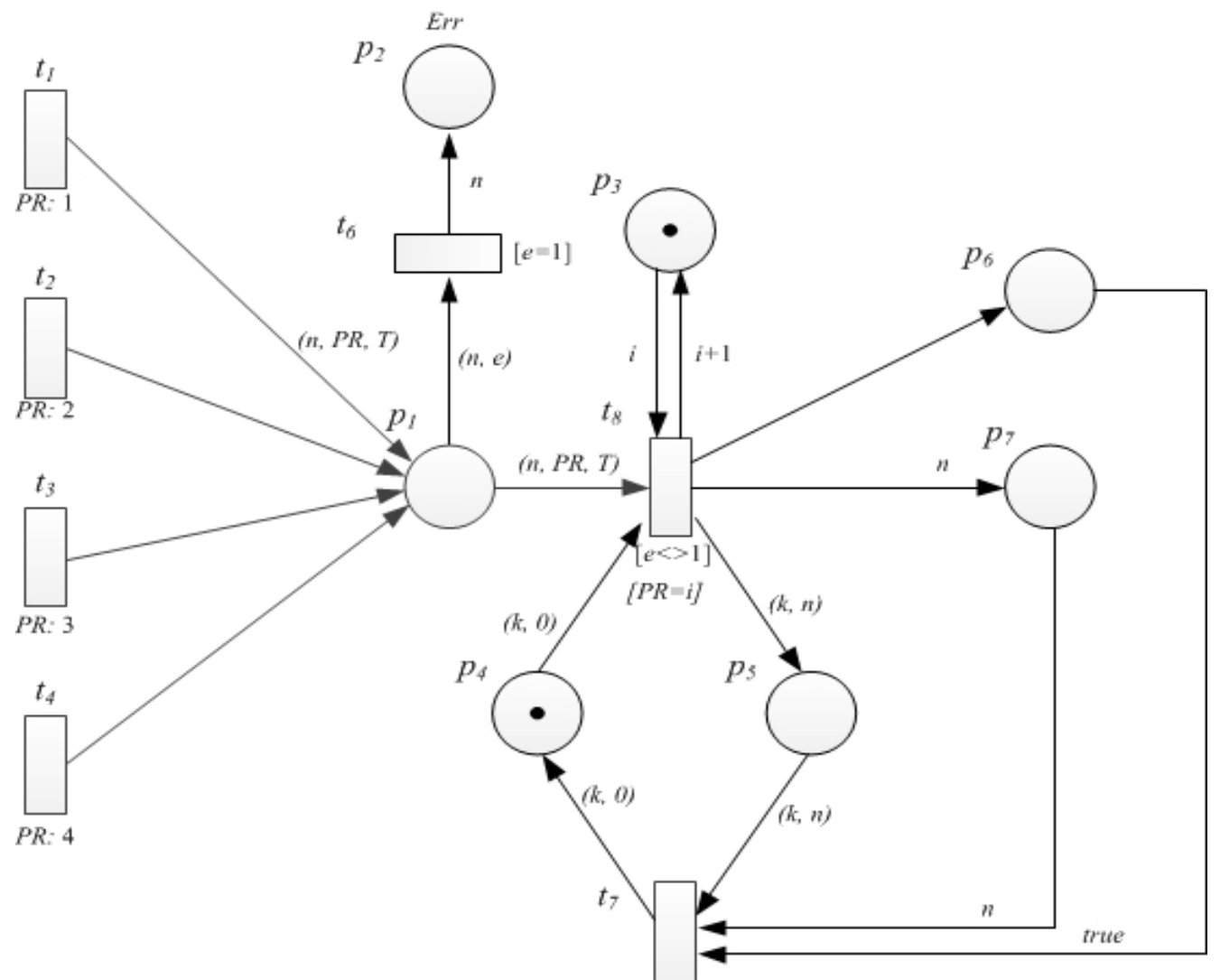

Рис. 3. Модель у мережах Петрі функціонування каналу передачі інформації

Кожна 3 фішок потрапляє до черги $\left(p_{1}\right), 3$ якої за пріоритетом виконується послідовна їх реалізація $\left(t_{8}\right)$
Це пов'язано з тим, що рух поїздів по станції здійснюється паралельно і можливі ситуації, коли одночасно необхідно оповістити декілька бригад, ДСП, локомотивні бригади, пасажирів та інших працівників.

Для пояснення функціонування каналу для передачі інформації розроблено відповідну модель у мережах Петрі (рис. 3). Подіями для формування оповіщення $\epsilon$ : робіт;

1) $t_{1}$ - поїзд, що прямує через зону виконання

2) $t_{2}$ - поїзд, що прямує по колії на небезпечній відстані від зони виконання робіт [7];

3) $t_{3}$ - встановлення маршруту через зону виконання робіт;

4) $t_{4}$ - встановлення маршруту по колії на небезпечній відстані від зони виконання робіт [7].

Для інших працівників подіями для формування оповіщення $\epsilon$ встановлення будь-якого маршруту $\left(t_{l}\right.$ або $t_{2}$ ) або наявність поїзду на передмаршрутній ділянці $\left(t_{3}\right.$ або $\left.t_{4}\right)$.

До кожної із зазначеної подій присвоєно відповідний пріоритет $P R$, що призначається фішці при ініціалізації.

Для аналізу моделі введено часовий механізм, реалізований за допомогою глобальних годин і штампів, які несуть фішки. Часовий штамп $T$ фішки призначається при іiі ініціалізації у початковій розмітці або при створенні фішки переходом і може нарощуватися виразами на переходах або дугах. У результаті, фішка стає доступною для переходу, якщо ії штамп виявився рівним значення лічильника глобальних годин. 
Рішення задачі вибору пріоритету реалізовано позицією-лічільником $p_{3}$, що містить фішку з поточним пріоритетом основного процесу та номер ресурсу $n$ для іiі подальшої ідентифікації.

Позиція $p_{6}$ виконує часову затримку виконання оповіщення $\left(p_{7}\right)$. На цей час канал переходить до стану зайнятості (фішка у позиції $p_{5}$ ).

У разі знаходження фішки у черзі більше дозволеного часу $T$ виконується фіксація помилки позицією $p_{2}$.

Отримані при моделюванні дані роботи каналу передачі інформації показали різке збільшення часу, за який необхідно починати оповіщення (рис. 4) при використанні одного каналу передачі.

Так, навіть за наявності однієї бригади працівників оповіщення необхідно виконувати за 124.9 с. до під’їзду поїзду, що майже у 2.5 рази більше встановленого [3] значення.

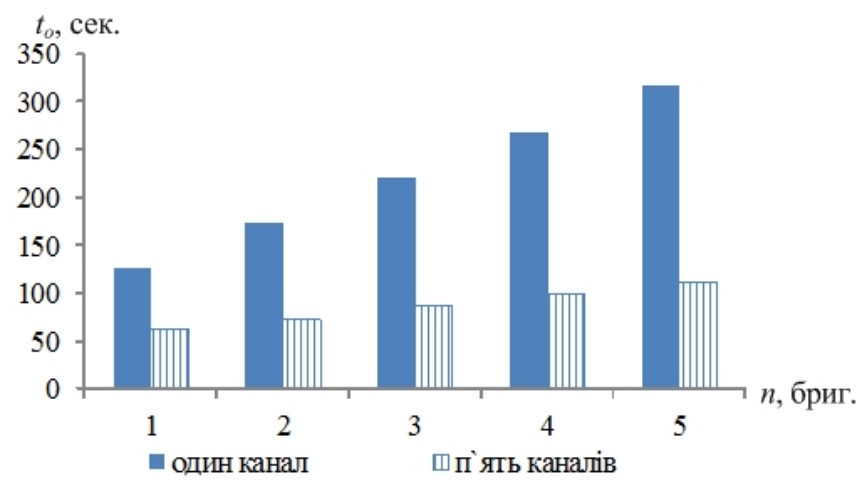

Рис. 4. Час, за який необхідно виконувати оповіщення при різних кількостях працюючих бригад

Рішенням проблеми зі значним передчасним оповіщенням $\epsilon$ використання окремого каналу для передачі мовного оповіщення для бригад працівників на коліях станції, чергового по станції, локомотивних бригад та пасажирів на платформах. Таким чином, час, за який необхідно розпочати оповіщення не перевищує встановлене значення на 12 секунд при наявності на коліях однієї бригади працівників.

\section{5. Висновки}

Представлене теоретичне обгрунтування кількості каналів передачі повідомлень в системі автоматичного оповіщення дозволило встановити, що для виконання своєчасного оповіщення всіх причетних до убезпеченого виконання робіт на коліях станції та попередження пасажирів на платформах (працівників на коліях, локомотивних бригад, чергового по станції та пасажирів) необхідно використовувати п'ять каналів, а час, за який необхідно розпочати оповіщення не перевищуватиме встановлене значення тільки на 12 секунд при наявності на коліях однієї бригади працівників.

Крім того, отримані дані дозволяють встановити послідовність оповіщення працівників на коліях та па- сажирів на платформах залізничних станцій в залежності від рівня небезпеки.

\section{Література}

1. Змій, С. О. Моделювання операцій оповіщення черговим по станції працюючих на коліях станції [Текст] / С. О. Змій, В. П. Мороз, Р. В. Турчинов // ВосточноЕвропейский журнал передовых технологий. - 2014. № 6/3 (72). - C. 26-29. doi: 10.15587/1729-4061.2014.31353

2. Train Activated Warning Systems. Railway Group Standart [Text] / GK/RT0029. - London, 1995. - 9 p.

3. Системы предупреждения работающих на железнодорожных путях и информирования пассажиров о приближении железнодорожного подвижного состава. Общие требования [Текст] / Национальный стандарт Российской Федерации ГОСТ Р 55804-2013. - Чинний від 2014.09.01. - М.: Стандартинформ, 2014. - 17 с.

4. Слюняев, А. Н. Централизованная система информирования и оповещения [Текст] / А. Н. Слюняев, Д. В. Ананьев, В. С. Андриенко, И. Д. Блиндер // Автоматика, связь, информатика. - 2012. - № 8. - С. 6-13.

5. Соболєв, Ю. В. Удосконалена автоматична система сповіщення працюючих на коліях - АСС УкрДАЗТ [Текст] / Ю. В. Соболєв, В. П. Мороз, О. В. Слізаренко та ін. // Збірник наукових праць Української державної академії залізничного транспорту. - 2005. - Вип. 121. - С. 233-239.

6. Кузнецов, Н. А. Методы анализа и синтеза модульных информационно-управляющих систем [Текст] / Н. А. Кузнецов та ін. - М.: ФИЗМАТЛИТ, $2002-792$ с.

7. Мороз, В. П. Метод визначення елементів колійного розвитку, що входять до зони виконання робіт на коліях [Текст] / В. П. Мороз, С. О. Змій // Збірник наукових праць ДонІЗТ. - 2014. - № 38. - С. 51-55.

\section{References}

1. Zmij, S. O., Moroz, V. P., Turchynov, R. V. (2014). Modeljuvannja operacij opovishhennja chergovym po stancii pracjujuchyh na kolijah stancii'. Vostochno-Evropejskyj zhurnal peredovih tehnologyj, 6/3(72), 26-29. doi: 10.15587/17294061.2014.31353

2. Railway Group Standart (1995). Train Activated Warning Systems. GK/RT0029. London, 9.

3. Sistemyi preduprezhdeniya rabotayuschih na zheleznodorozhnyih putyah i informirovaniya passazhirov o priblizhenii zheleznodorozhnogo podvizhnogo sostava. Obschie trebovaniya (2013). Natsionalnyiy standart Rossiyskoy Federatsii GOST R 55804-2013ю Standartinform, 17.

4. Slyunyaev, A. N., Ananev, D. V., Andrienko, B. C., Blinder, I. D. (2012). Tsentralizovannaya sistema informirovaniya i opovescheniya. Avtomatika, svyaz, informatika, 8, 6-13.

5. Soboliev, Yu. V., Moroz, V. P., Yelizarenko, O. V., Yelizarenko, A. O., Moroz, O. V. (2005). Udoskonalena avtomatychna systema spovishchennia pratsiuiuchykh na koliiakh . Zbirnyk naukovykh prats Ukrainskoi derzhavnoi akademii zaliznychnoho transport, 71, 233-239.

6. Kuznetsov, N. А. (2002)ю Metodyi analiza i sinteza modulnyih informatsionno-upravlyayuschih system. Moscow: FIZMATLIT, 792.

7. Moroz, V. P., Zmij, S. O. (2014). Metod vyznachennja elementiv kolijnogo rozvytku, shho vhodjat' do zony vykonannja robit na kolijah. Zbirnyk naukovyh prac DonIZT, 38, 51-55.

Рекомендовано до публікаиії д-р техн. наук Бойнік А. Б. Дата надходження рукопису 23.12.2014

Змій Сергій Олексійович, асистент, кафедра автоматики та комп'ютерного телекерування рухом поїздів,

Українська державна академія залізничного транспорту, пл. Феєрбаха, 7, м. Харків, Україна, 61050

E-mail: onilsergey@yandex.ru 